\title{
Doctrines of the Great Educators
}




\section{Doctrines of the Great Educators}

Robert R. Rusk and

James Scotland

FIFTH EDITION

St. Martin's Press New York 
(c) R.R. Rusk 1965,1969

(c) New material, James Scotland 1979

All rights reserved. For information, write:

St. Martin's Press, 175 Fifth Avenue, New York, N.Y. 10010

Printed in Great Britain

Fifth edition first published in the United States of America in 1979

Reprinted 1987

ISBN 978-0-333-23221-7 ISBN 978-1-349-16075-4 (eBook)

DOI 10.1007/978-1-349-16075-4

Library of Congress Cataloging in Publication Data

Rusk, Robert Robertson, 1879-1972.

Doctrines of the great educators.

Bibliography: p.

Includes index.

1. Education-History 2. Educators

I. Scotland, James, joint author. II. Title

$\begin{array}{llll}\text { LA13.R85 } & 1979 & 370.1 & 78-12874\end{array}$

ISBN 978-0-312-21491-3

ISBN 978-0-312-21492-0 pbk. 


\section{Contents}

Preface vii

1 'The Great Educators' 1

$\begin{array}{lll}2 & \text { Plato } & 7\end{array}$

3 Quintilian 35

4 Loyola 46

5 Comenius 62

6 Locke $\quad 80$

$\begin{array}{lll}7 \text { Rousseau } & 100\end{array}$

8 Pestalozzi 136

9 Herbart 155

$\begin{array}{lll}10 & \text { Froebel } & 178\end{array}$

11 Montessori 193

12 Dewey 215

13 The Twentieth Century 233

Notes and References $\quad 247$

Bibliography 293

Index 303 


\section{Preface to the Fifth Edition}

Dr Robert Rusk died in 1972, at the age of ninety-three, his energy undimmed. This book went through four editions and seventeen impressions during his lifetime, and it has been reprinted three times since his death. It is a classic of educational exposition.

For this new edition I have made some alterations, omissions and additions. I have dropped three of Rusk's chapters, those on Elyot, Milton and Whitehead. The first two were included as representative of English educators in the period of the Renaissance and Reformation, but they do not seem to me to satisfy all the criteria Rusk adopted for a 'Great Educator': few students, even specialists, would claim much currency for their educational doctrines today. Some of these doctrines, especially Elyot's, I have added to the beginning of the chapter on Loyola. Whitehead did not make his appearance in the book until its fourth edition, and in the event his philosophy has proved to be less influential than it promised. Nevertheless his ideas still have power, and they have been given their place in the last chapter.

That chapter is itself an addition. The outstanding educators of the seventeenth, eighteenth and nineteenth centuries virtually select themselves; but after Dewey, who?* There have been many writers of stature in the last half-century, perhaps too many. Piaget would have his supporters, and detractors; so would Neill, Bruner and Illich. There is a good case for suggesting that the ideas of Marx and Freud (and for that matter Nietzsche) have had more influence in our education than those of any educational specialist. But fashions change: today's Peter the Apostle looks tomorrow

* Dewey himself did not make his appearance until the second edition. 


\section{viii Doctrines of the Great Educators}

like Peter the Hermit. The last chapter is my attempt to discern patterns in the spate of recent ideas.

To smooth continuity I have introduced a little extra material into each chapter - at the beginning a short biographical sketch, with some suggestions concerning influences at work on the educator concerned; at the end a few remarks on his impact in schools, colleges and educational systems. For students I have rectified an omission Rusk himself intended to repair, by adding short bibliographies. And, as is fitting in a new edition, I have amended the text in places to take account of a decade of recent scholarship.

This last task has not been onerous. Generally it has amounted to providing alternative readings and fresh emphases, seldom to introducing corrections. This is because Rusk worked habitually from the original texts or the best translations; what we have is his interpretation of the author's own statements, not his summary of another critic's commentary. In consequence many pages of the last edition he revised appear unchanged in this. One would expect no less of a book going into a new edition after sixty years. It is a measure of Robert Rusk, who was my own master, over thirty years ago, in the University of Glasgow.

September 1977

James Scotland 